\title{
Monumentos da cidade de São Paulo: formas de alteração e conservação
}

Aranda Calió dos Reys ${ }^{*}$, Eliane Aparecida Del Lama** e Lauro Kazumi Dehira***

\section{Resumo}

Monumentos históricos são parte do patrimônio cultural de um povo ou de uma nação, servindo como elo entre o presente e o passado. A sua manutenção e conservação deve ser realizada, para que as pessoas que os cercam possam de alguma forma usufruí-los e preservá-los para as gerações futuras. A forma mais eficaz de preservação do patrimônio cultural é através da educação patrimonial, na qual a população adquire consciência de seu papel de salvaguarda de suas relíquias.

O intemperismo das rochas é um processo natural, mesmo nos monumentos históricos. Contudo, sua velocidade vem aumentando consideravelmente em função da crescente poluição da atmosfera urbana, que favorece a degradação dos materiais rochosos dos monumentos.

A presente pesquisa objetivou a identificação e análise dos tipos e das formas de alteração, degradação e das intervenções já realizadas nos monumentos do "Centro Velho de São Paulo" e adjacências.

A análise do estado de conservação dos monumentos foi realizada por meio de um levantamento das morfologias de alteração das obras que foram avaliadas macroscópica e microscopicamente. Para tanto, utilizaram-se análises de microscopia eletrônica de varredura (MEV), difratometria de raios $X(D R X)$ e microscopia petrográfica.

Durante as vistorias em campo, constatou-se a existência de níveis diferenciados de degradação e de feições de intemperismo, que foram catalogados e analisados.

Palavras-chave: Conservação. Monumentos. São Paulo.

\section{Abstract}

Historic monuments are part of the cultural heritage of a people or a nation, linking the present to the past. They should be preserved in a way that people can make good use of them and preserve them for the future generations. The most effective form of conservation of the cultural heritage is the patrimonial education, through 
which the population acquires awareness of their own role as guardian of their antiquities.

The weathering of the rocks in historic monuments is a natural process. However, its velocity has increases substantially due to the increase of the urban atmospheric pollution, that facilitates the degradation of stones and rocks of the monuments.

The present research focused the identification of the forms of alteration, degradation and intervention that have already been done in monuments in São Paulo.

The analysis of the conditions of the monuments was based in field work which resulted in a catalogue of the alteration morphologies, which were characterized both macro and microscopically. For this, scanning electron microscopy (SEM), X-ray diffraction (XRD) and petrography microscopy techniques were used.

During the field work it was observed the existence of distinctive forms of degradation and weathering characteristics that were analyzed and catalogued.

Keywords: Conservation. Monuments. São Paulo.

\section{Introdução}

A vida de uma cidade é um acontecimento contínuo, que se manifesta ao longo dos séculos por obras, materiais, traçados ou construções que the conferem personalidade própria, e dos quais emana pouco a pouco a sua alma.

Essas manifestações são testemunhos preciosos do passado que devem ser respeitados por seu valor histórico ou sentimental. Eles fazem parte do patrimônio humano, e aqueles que os detêm, ou são encarregados de sua proteção, têm a responsabilidade e a obrigação de conservá-los e transmitir para os séculos futuros esse nobre patrimônio.

A cidade de São Paulo possui cerca de 440 obras de arte e monumentos públicos.

Muitos monumentos históricos, esculpidos em granito ou mármore, apresentam processos de degradação que comprometem a estrutura estética do conjunto arquitetônico de São Paulo. A deterioração destas rochas pode ocorrer tão 
lentamente que se torna pouco perceptível ao longo do ciclo de vida humana. Porém, algumas de suas partes chegam a ser alteradas com maior facilidade tanto devido às suas características intrínsecas como pela degradação antrópica. Esta é conseqüência da urbanização, e fatores como poluição, deslocamento das obras e vandalismos (1) aceleram o processo intempérico.

Para este estudo foi selecionada principalmente a região central, o chamado "centro velho" de São Paulo, para avaliação do estado de conservação e identificação das formas de alteração e degradação de algumas obras, através da análise das alterações mineralógicas e texturais ocorridas nas rochas que as compõem e as intervenções já realizadas. Para tanto, objetivando a comparação da degradação das obras em regiões distintas, foram analisadas obras em regiões mais periféricas, principalmente próximo à Cidade Universitária, Ibirapuera, Aclimação, Avenida Paulista e Higienópolis.

\section{Conservação de monumentos}

Ao longo do tempo, a rocha é o material, no mundo todo, que mais tem sido utilizado na construção de monumentos. No passado, os reparos eram feitos jogando-se fora a rocha degradada, recolocando-se um novo material parecido com o anterior, o que destruía toda originalidade do monumento.

Com o avanço científico e técnico da humanidade, não só novos materiais e técnicas de construção e restauração foram se desenvolvendo, como também novas atitudes foram sendo criadas no sentido de valorizar e restaurar os bens patrimoniais (SMITH, 1999).

Qualquer patrimônio histórico, esteja onde estiver, deve ser salvaguardado, pois os monumentos permitem a "leitura" dos fatos ocorridos, representando um precioso testemunho do passado, tanto pelo seu valor histórico, como cultural. As obras do passado demonstram como cada geração, com os recursos técnicos disponíveis, teve maneiras diferentes de representar suas idéias, sua estética e imaginação.

De acordo com o artigo terceiro da Carta Internacional sobre a Conservação e o Restauro de Monumentos e Sítios, "A conservação e o restauro dos monumentos 
têm como objetivo salvaguardar tanto a obra de arte como as respectivas evidências históricas." (CARTA DE VENEZA, 1964).

Portanto, seguindo os preceitos da Carta de Veneza, todos aqueles que estão encarregados de sua proteção - organizações públicas e/ou privadas - têm a responsabilidade de transmitir para as gerações futuras essa nobre herança.

No sentido de se conservar um patrimônio público, é essencial que se combinem recursos técnicos e respeito às cartas patrimoniais. Vale ressaltar que a real conservação de todo e qualquer monumento só pode ser garantida através do respeito e do interesse da população, pois é ela quem pode exigir e controlar ações dos poderes públicos e privados em relação ao patrimônio. Assim, ela deve ser educada, desde a infância, a respeitar, valorizar e proteger os testemunhos de toda a civilização.

\subsection{Conservação e degradação dos monumentos}

Comparando-se com a escala do tempo de vida humana, o intemperismo ocorre lentamente devido à complexa composição das rochas mais resistentes, que retardam as reações de degradação. Mas quando há influência antrópica, a situação é outra: o aumento na concentração de poluentes, o teor de partículas que aderem à superfície das obras e o vandalismo são fatores que influenciam na aceleração da degradação intempérica.

Os tipos principais de degradação de rochas para revestimento ou de monumentos foram apontados por Aires-Barros (1991) como sendo químico, físico e biológico. A degradação química considera as reações que se processam na superfície e nas descontinuidades das rochas, com a formação de minerais secundários. A degradação física resulta de fenômenos de expansão e contração dos minerais, provocados por variações térmicas, abalos físicos de várias origens, e ainda por expansões decorrentes da geração de minerais secundários (hidratação de minerais argilosos expansivos, ação da tensão superficial da água no decurso de processos naturais de saturação e secagem, e ação das forças de cristalização de sais). A degradação biológica é provocada pelo crescimento de microorganismos sobre as rochas. 
Considerando as condições climáticas e técnicas construtivas empregadas no Brasil, Frascá (2002) aponta as seguintes causas da degradação de materiais rochosos:

- clima tropical (grandes variações de temperatura e umidade);

- agentes de limpeza, os quais utilizam diversas substâncias químicas, cujos componentes podem causar modificações, especialmente no aspecto estético das rochas;

- poluição ambiental, na qual os diversos elementos dispersos na atmosfera têm grande influência;

- cristalização de sais, principalmente quando as rochas são usadas no revestimento de pisos e assentamentos com argamassa.

A interação das características petrográficas, físicas e mecânicas das rochas com os agentes do meio ambiente e os procedimentos de fixação, limpeza e manutenção executados por não-especialistas têm conduzido à deterioração das rochas. Resultam na alteração da superfície exposta da rocha, modificando ou danificando seu aspecto estético, pela perda de brilho e manchamentos (FRASCÁ, 2003).

Dependendo das condições ambientais e das características dos materiais estudados, diferentes formas de intemperismo podem ocorrer, tais como: fissuras, crostas negras (relacionadas à poluição atmosférica), desintegração granular, erosão, eflorescência, colonização biológica, placas e esfoliação.

Fitzner et al. (1995) criaram uma classificação para o mapeamento das formas de intemperismo dos monumentos. Seu método de trabalho baseou-se no diagnóstico, registro, documentação e avaliação dos danos causados nas obras estudadas, e pode ser aplicado em qualquer tipo de rocha e monumento natural. Esta classificação foi apresentada como um atlas de fotos em Fitzner \& Heinrichs (2004).

Um método mais simplificado de classificação das formas de intemperismo é adotado por Henriques et al. (2005). 
Para os trabalhos de conservação das obras é necessário haver informações técnicas a respeito dos tipos de rochas que foram utilizadas e suas respectivas condições de uso e de ambiente em que se encontram, as quais subsidiam o planejamento de medidas de restauro e conservação.

O descuido na manutenção dos monumentos, assim como o uso de métodos inapropriados, resulta em sua deterioração. Os primeiros sinais são aparecimento de manchas, rachaduras e depressões. Em Smith (1999) pode ser encontrada uma substancial avaliação sobre esta questão:

- o aparecimento de manchas dá-se, sobretudo, devido ao uso de altas concentrações de cimento portland na argamassa. Este uso deve ser compatível com a rocha. Por exemplo: em uma rocha porosa, a utilização de argamassa inadequada pode levar à drenagem e percolação de águas pluviais, e o congelamento desta água retida pode danificar a superfície da rocha;

- a corrosão dos adornos metálicos permite a formação de manchas amarronzadas, causadas pelo óxido e hidróxido de ferro, e manchas esverdeadas, derivadas do cobre;

- as rachaduras, quebras e lascas podem ter como causa, entre outras, o transporte inadequado da obra, a cristalização de sais introduzidos pelo cimento utilizado nas argamassas, a geada, por meio da expansão do volume da água durante o congelamento e/ou pressão hidráulica interna nos poros da rocha;

- problemas na alvenaria, causados pela corrosão de vigas de aço, parafusos, pregos, etc., desfavorecem a rocha causada pelo ingresso de água em sua estrutura;

- o calor excessivo ou ventilação inadequada podem danificar as obras. Também os visitantes aumentam a umidade relativa dentro da construção, causando condensação nas paredes e/ou recristalização de sais solúveis que absorvem a água, danificando a estrutura da obra;

- o uso de produtos de limpeza, abrasivos e tinturas gera descoloração, manchas e eflorescências;

- algas, fungos, liquens e bactérias podem crescer e alojar-se nas superfícies da rocha;

- abelhas e pássaros (e seus detritos fecais) podem se instalar nas obras, deteriorando-as; 
- árvores podem encobrir os monumentos e aumentar a umidade local;

- erosão eólica pode causar alveolização em algumas rochas, tais como arenitos e calcários;

- poluentes advindos, por exemplo, de óxidos de nitrogênio (motores de veículos), chuva ácida, emissões de diesel, e fertilizantes afetam, consideravelmente, as obras;

- nas rochas que contêm calcita, as variações termais provocados pelo sol causam expansões térmicas irreversíveis;

- nas rochas calcárias "atacadas" por agentes poluidores, principalmente dióxido de enxofre e óxido de nitrogênio, ocorrem perda de massa, descoloração e alteração da porosidade; em casos de menor poluição, estas rochas são dissolvidas pela ação da chuva ácida.

Entre as características intrínsecas da rocha, a porosidade e a presença de espécies mineralógicas solúveis (carbonatos e sulfatos) ou de volume variável dependendo do grau de umidade (argilas expansivas) são as mais importantes no intemperismo de um material. Dentre os fatores externos, a cristalização de sais na zona de intemperismo é um fato característico, conduzindo a um maior grau de deterioração (VICENTE et al., 1996).

Wilczynska-Michalik (2004) apresenta a cristalização de sais e seu "papel destrutivo" em rochas porosas em áreas urbanas altamente poluídas, tomando como estudo de caso Cracóvia, na Polônia. Reproduzindo em laboratório as mesmas condições ambientais sofridas pela rocha, ela pôde observar e estudar as eflorescências (cristalizações de sais) e as crostas negras. Segundo a autora, a principal razão da deterioração dos materiais vem, geralmente, de sua reação com os poluentes atmosféricos e com a cristalização de sais, ou seja, o intemperismo de sais destrói a textura das rochas primárias, provocando sua deterioração.

Prikryl et al. (2004) constataram que num ambiente poluído com excesso de sulfato é comum a formação de crostas negras e mudanças cromáticas nas rochas. Analisando três esculturas de arenito em Praga, observaram a presença de crostas micrométricas a milimétricas compostas principalmente de sulfatos. Apesar de a gipsita ser o mineral predominante, outras fases neo-formadas aparecem, 
constituindo uma composição química incompatível com a rocha original, podendo indicar que a fonte desse material é oriunda de produtos químicos usados na pintura, limpeza, remoção de pintura e conservação da rocha.

O termo crosta negra, apesar de ser muito utilizado, nem sempre tem o mesmo significado. Crosta é a interação do material pétreo e a atmosfera, ou seja, é uma transformação na parte mais superficial do monumento, que adquire coloração preta se houver deposição de sujeira nesta superfície (DELGADO RODRIGUES, 2006a). Este processo é comum em rochas carbonáticas.

\subsection{Restauração}

De acordo com o artigo nono da Carta de Veneza (1964):

O restauro é um tipo de operação altamente especializado. O seu objetivo é a preservação dos valores estéticos e históricos do monumento, devendo ser baseado no respeito pelos materiais originais e pela documentação autêntica.

O conceito pode ser complementado com o artigo quarto da Carta de Restauro (1972):

[...] entende-se por restauração qualquer intervenção destinada a manter em funcionamento, a facilitar a leitura e a transmitir integralmente ao futuro as obras e os objetos [...].

As intervenções efetuadas nas obras durante o restauro não devem ultrapassar o limiar da preservação do valor intrínseco do objeto. Por esta razão, antes da intervenção, é necessário definir uma estratégia de restauração e análise crítica das ações a serem definidas e executadas.

A preservação das superfícies justifica a sua limpeza, já que elimina substâncias nocivas. Mas não se deve buscar com este método uma superfície limpa, e sim, uma imagem que não prejudique a leitura da obra, ou seja, uma leitura harmoniosa e que possibilite a identificação da edificação. 
O princípio da intervenção mínima deve ser estabelecido e seguido pelos restauradores respeitando a ética da conservação.

Uma intervenção inadequada pode ocasionar situações irreversíveis destruindo a superfície original da rocha.

As intervenções modificam o contexto histórico de um monumento. Por esta razão, é recomendado que seja dada prioridade à manutenção ao invés de intervenção.

O importante é documentar e registrar todas as ações realizadas durante o restauro: metodologia empregada, materiais, análises e processos usados, para servir de suporte a futuras gerações, sem causar enviesamento da cultura artística e histórica do monumento.

O Claustro do Mosteiro dos Jerônimos (Lisboa), por exemplo, pode ser considerado um bom exemplo de restauração. Realizaram-se na obra: eliminação de problemas de infiltração de água, realinhamento e estabilização de blocos de pedra, abertura de todas as juntas não-funcionais e preenchimento com argamassa apropriada, limpeza, consolidação de áreas deterioradas e aplicação de acabamentos superficiais de proteção. Essas intervenções são pormenorizadas em Instituto Português do Património Arquitectónico IPPAR (2006).

\section{Métodos de trabalho}

Para a realização do presente estudo, foram selecionadas diversas obras para avaliação do seu estado de conservação e caracterização das formas de intemperismo nelas presentes.

Para cada obra estudada foi elaborada uma ficha conforme modelo de Reys (2006). As fichas foram elaboradas a partir da compilação dos dados obtidos no Departamento de Patrimônio Histórico (DPH) da cidade de São Paulo, acrescidos da avaliação do atual estado de conservação das obras e do registro fotográfico obtidos nos levantamentos de campo.

A relação dos monumentos e a sua localização é a que se segue: 
1. A Menina e o Bezerro, de Charles Louis Eugène Virion - Largo do Arouche;

2. Amizade Sírio-Libanesa, de Ettore Ximenez - Praça Ragueb Chohfi;

3. Amor Materno, de Charles Louis Eugène Virion - Largo do Arouche;

4. Anhangüera, de Luigi Brizzolara - Avenida Paulista;

5. Aretuza, de Francisco Leopoldo da Silva - Parque Trianon;

6. Camões, de José Cucê - Praça Dom José Gaspar;

7. Cervantes, de Rafael Galvez - Praça Dom José Gaspar;

8. Dança Branca, de Arcângelo lanelli - Parque da Aclimação;

9. Depois do Banho, de Victor Brecheret - Largo do Arouche;

10. Discóbolo, de Ottoni Borilini - Praça General Polidoro;

11. Duque de Caxias, de Victor Brecheret - Praça Princesa Isabel;

12. Fauno, de Victor Brecheret - Parque Trianon;

13. Fonte Monumental, de Nicolina V. A. P. do Couto - Praça Júlio de Mesquita;

14. Glória Imortal aos Fundadores de São Paulo, de Amadeu Zani - Páteo do Colégio;

15. Mãe, de Caetano Fracarolli - Praça Buenos Aires;

16. Mãe Preta, de Júlio Guerra - Largo do Paissandu;

17. Monumento às Bandeiras, de Victor Brecheret - Praça Armando de S. Oliveira;

18. Monumento a Carlos Gomes, de Luiz Brizzolara - Praça Ramos de Azevedo;

19. Monumento a Ramos de Azevedo, de Galileo Emendabili - Cidade Universitária;

20. Nostalgia, de Francisco Leopoldo da Silva - Praça Prof. Cardim;

21. Obelisco, de Galileo Emendabili - Parque do Ibirapuera;

22. Obelisco da Memória, de Vicente Pereira - Ladeira da Memória;

23. O Ceifador, de Mathurin Moreau - Praça Prof. Resende Poech;

24. Os Fundadores de São Paulo, de Luiz Morrone - Rua Manuel da Nóbrega;

25. Padre José de Anchieta, de Heitor Usai - Praça da Sé;

As obras de números 16, 17, 18, 21 e 22 são tombadas pelo órgão municipal de preservação do patrimônio histórico. 
Cada obra visitada foi fotografada em diferentes ângulos a fim de registrar todos os tipos de intemperismo e degradação encontrados. As rochas foram descritas macroscopicamente com auxílio de lupa de mão, detalhando as feições de degradação e de composição. Registrou-se também o entorno (localização e condições ambientais) de cada obra.

Durante as visitas de campo foram coletadas, quando presentes, amostras para análise composicional e estrutural das deposições superficiais (fuligem e material orgânico), eflorescências, concreções de argamassa e caiação (amostras de cal), para determinação dos impactos sofridos ao longo do tempo pela rocha. Ressalta-se que o DPH cedeu ao projeto amostras mesoscópicas guardadas de fragmentos caídos ou danificados de monumentos, para a execução das análises. Com isso, deixa-se claro que, em hipótese alguma, as obras foram danificadas para obtenção de amostras para este estudo.

Foram realizadas análises de difratometria de raios $X(D R X)$ e microscopia eletrônica de varredura (MEV) com EDS (espectroscopia de energia dispersiva de raios $\mathrm{X}$ ) acoplado em amostras de crostas, concreções e eflorescências coletadas de cinco monumentos, e microscopia petrográfica em amostras de dois monumentos cedidas pelo $\mathrm{DPH}$.

\section{Métodos analíticos}

Para o estudo das características mineralógicas, morfológicas, químicas e estruturais dos materiais cristalinos ou orgânicos foram utilizados métodos que, individualmente ou combinados, permitiram a identificação de feições e anomalias significativas para cada monumento.

Primeiramente, a identificação do material se deu por meio de lupa de mão e estereomicroscopia. Foram utilizados os seguintes métodos analíticos: microscopia eletrônica de varredura (MEV) com EDS, difratometria de raios $X(D R X)$ e microscopia petrográfica. As análises foram realizadas nos laboratórios do Instituto de Geociências da Universidade de São Paulo (IGc-USP). 
A escolha das técnicas analíticas para determinadas amostras deu-se em função da disponibilidade e quantidade das amostras obtidas em trabalhos de campo e as amostras cedidas pelo DPH.

Foram analisadas amostras por microscopia eletrônica de varredura dos seguintes monumentos: Amizade Sírio-Libanesa, O Ceifador, Monumento às Bandeiras, Nostalgia e Monumento a Ramos de Azevedo.

Foram analisadas amostras por difratometria de raios $\mathrm{X}$ dos seguintes monumentos: Amizade Sírio-Libanesa, Amor Materno, Monumento às Bandeiras e Monumento a Ramos de Azevedo.

Nas argamassas de rejunte analisadas foi diagnosticada a calcita, sendo que a dolomita também se faz presente no Monumento a Ramos de Azevedo. Neste último monumento foi detectado chumbo, provavelmente oriundo de poluentes atmosféricos.

Nas amostras estudadas foi observada a presença de microorganismos, diagnosticada pelo Prof. Dr. Thomas R. Fairchild e pela Dra. Wania Duleba, ambos do IGc-USP.

Foram diagnosticadas estruturas biológicas em argamassas e fuligem, tais como: esporos e filamentos de fungos, cianobactérias, ramificações de um possível líquen, fibra vegetal (material alóctone), foraminíferos e conchas de moluscos.

Em amostra de eflorescência na estátua de bronze Depois do Banho constatou-se a presença da gipsita $\left(\mathrm{CaSO}_{4} \cdot 2 \mathrm{H}_{2} \mathrm{O}\right)$. É provável que a formação deste sal esteja ligada aos poluentes atmosféricos, uma vez que sulfato e cálcio não são constituintes desta liga metálica. Em amostras de fuligem também foi detectada gipsita, sendo mais uma indicação que o sulfato seja oriundo de poluentes atmosféricos.

Foram obtidas duas amostras para o estudo petrográfico: Amizade Sírio-Libanesa e Anhangüera. 
A rocha constituinte do monumento Amizade Sírio-Libanesa é um granito. A associação mineralógica da rocha é a seguinte: quartzo (38\%), oligoclásio (35\%), feldspato potássico (26\%), biotita e clorita (1\%), e traços de minerais opacos, apatita, fluorita, muscovita, zircão e titanita.

A rocha constituinte do monumento Anhangüera é um calcário fossílifero, composta exclusivamente por calcita espática. Ocorre presença de foraminíferos, oóides, bioclastos e intraclastos, sendo observados grãos alobioquímicos no arcabouço carbonático de granulação fina.

O detalhamento da parte analítica pode ser obtido em Reys (2006).

\section{Análise do estado de conservação dos monumentos estudados}

Conservação é um conjunto de ações destinadas a dotar o objeto/monumento de condições para melhor resistir aos agentes de degradação (DELGADO RODRIGUES, 2006b).

A análise do estado de conservação foi feita com base nas condições ambientais e nas condições geológicas (intempéricas) observadas nos monumentos estudados da cidade de São Paulo.

Em muitos casos foram observadas más condições de conservação do entorno (praças, parques e ruas) dos monumentos. Estas áreas apresentam-se sujas (lixo doméstico) e mal cuidadas. Há regiões vizinhas às obras que apresentam ambulantes e moradores de ruas, que utilizam os monumentos como banheiro (presença de urina e fezes, tanto de animais, como humanas) e moradia. Muitas árvores precisam ser podadas, já que dificultam a visualização do monumento e provocam o aumento da umidade devido às chuvas.

Esses fatores contribuem para a desvalorização do patrimônio histórico e turístico da cidade, além de induzir a degradação dos monumentos. 
Algumas obras, como Mãe Preta, são usadas em rituais religiosos, retratando uma questão sócio-cultural em que as estátuas podem ser inseridas. Neste caso, o monumento é considerado como "imagem religiosa". Geralmente, nestes casos, ocorre carbonização da base da obra, devido à presença constante de queima de velas, que agridem diretamente a rocha em questão. Isto pode ser verificado com a presença de parafinas de velas derretidas "aos pés" ou sobre a obra.

Em 2001, o Parque da Aclimação teve duas estátuas de mármore (Todas as Manhãs e Os Amantes) destruídas por ataque de vandalismo. Outras duas obras foram doadas ao parque em substituição, Forma Rompida e Retorno, de mesma autoria das anteriores. Estas últimas foram confeccionadas em placas de ferro, pintadas de branco, com base em concreto (presença de pregos grandes aparentes).

Há casos em que obras são depredadas parcialmente, como o Anhangüera, em que ornamentos presentes em sua base de calcário fossilífero foram destruídos (Fig. 1). Com isso, não houve apenas perda estética, mas também perda do contexto histórico e arqueológico da obra. Outras obras que apresentam depredações parciais: A Menina e o Bezerro, Amor Materno, Aretuza, Discóbolo, Duque de Caxias, Fonte Monumental, Mãe, Monumento a Carlos Gomes, Nostalgia e O Ceifador. 


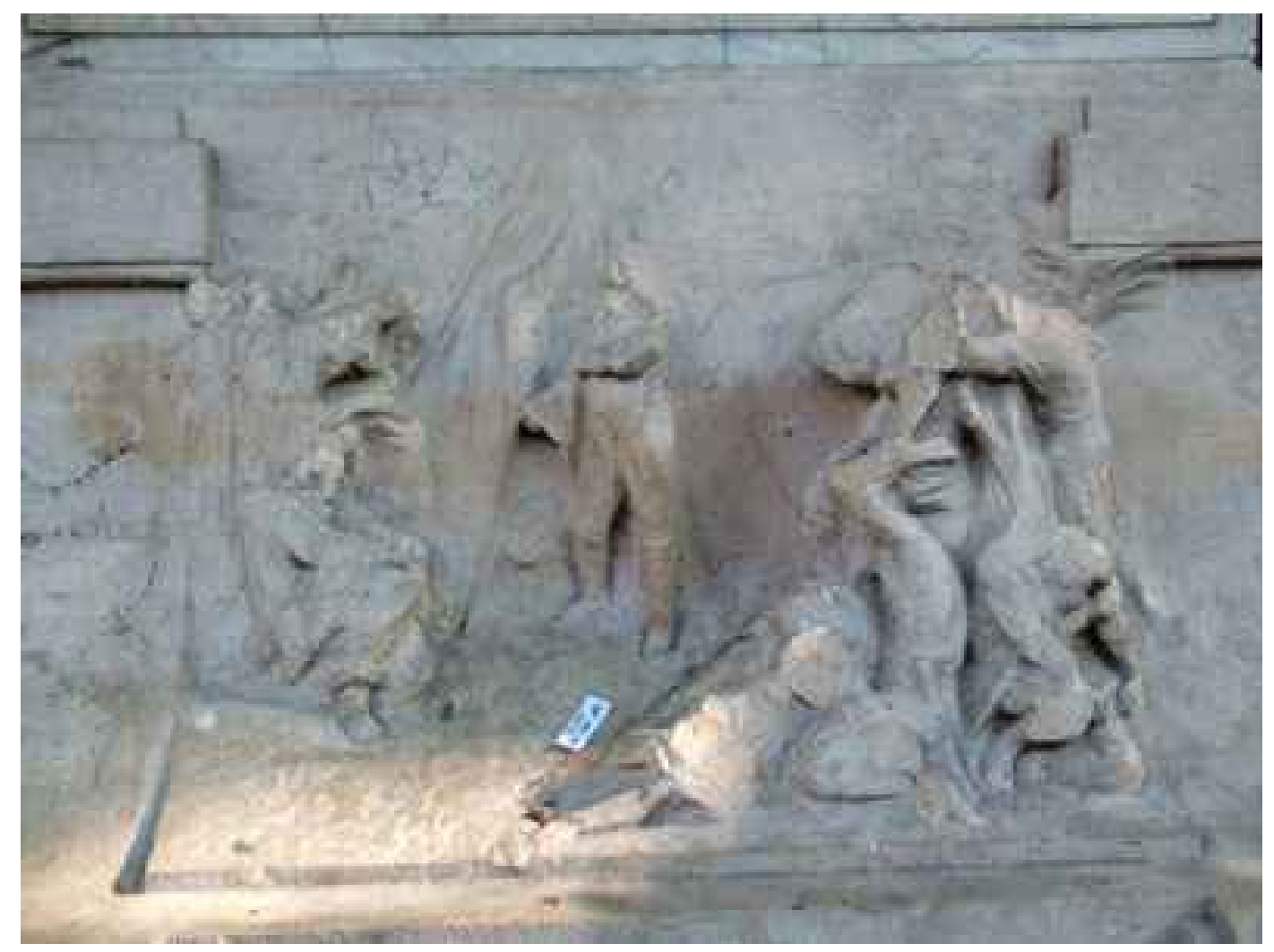

Figura 1

É bastante comum nos defrontarmos com as lamentáveis notícias de roubos de placas de identificação dos monumentos (A Menina e o Bezerro, Amor Materno, Amizade Sírio-Libanesa, Amor Materno, Anhangüera, Mãe Preta, Nostalgia e Padre José de Anchieta) assim como outras partes, principalmente materiais em bronze (Fonte Monumental). Muitas vezes, em decorrência do roubo e retirada de partes do monumento, as estruturas das obras ficam expostas, como no caso do monumento Os Fundadores de São Paulo.

Quinas quebradas são visualizadas freqüentemente nas obras, e podem estar relacionadas à depredação ou ao deslocamento dos monumentos. Foram observadas nos monumentos: A Menina e o Bezerro, Nostalgia, Amizade SírioLibanesa, Anhangüera, Glória Imortal aos Fundadores de São Paulo, Mãe, Monumento a Ramos de Azevedo, Nostalgia, Obelisco da Memória e O Ceifador.

Muitas obras apresentam pichações com tinta, spray, caneta ou até giz de cera (é o caso de $\mathrm{O}$ Ceifador, que se localiza em frente a uma escola infantil, retratando a necessidade de implantação de educação patrimonial nas escolas). Outras obras 
que apresentam pichações: Amizade Sírio-Libanesa, Amor Materno, Anhangüera, Depois do Banho, Discóbolo, Duque de Caxias, Fonte Monumental, Os Fundadores de São Paulo, Mãe, Mãe Preta, Monumento às Bandeiras, Monumento a Ramos de Azevedo, O Ceifador e Padre José de Anchieta.

Entre setembro e outubro de 2006, o Monumento às Bandeiras foi pichado duas vezes, demonstrando que é preciso vigilância, pelo menos nos monumentos mais representativos da cidade. $O$ desconhecimento é também da mídia, uma vez que a legenda em foto de reportagem sobre a última pichação no Monumento às Bandeiras dizia que seria necessário contratar uma empresa especializada em jato de areia para eliminar a pichação. Frisa-se aqui que este método não é uma prática aceitável em conservação de monumentos históricos.

Vestígios de pichações foram observados em alguns monumentos após a sua limpeza. Estes vestígios são decorrentes de pichações com uso de tintas (e sprays) insolúveis que penetram nos poros da rocha, impossibilitando que produtos solúveis usados para sua remoção, consigam penetrar nos poros da rocha. Este caso tornase ainda maior quando se trata de uma rocha com alta porosidade, como são as rochas carbonáticas. É justamente nestes casos que não se deve utilizar meios mecânicos que degradem o substrato, como jato de areia, na intenção de remover a pichação por completo. Foram observados nos monumentos: Aretuza, Camões, Cervantes, Monumento a Carlos Gomes, Nostalgia, Obelisco e Obelisco da Memória.

Um outro problema grave que afeta os monumentos é a ação de pombos, que infestam as áreas urbanas. Suas fezes mancham as obras, devido ao alto conteúdo de nitrato, como observado nos monumentos Duque de Caxias, Glória Imortal aos Fundadores de São Paulo e Mãe.

O uso da argamassa durante a restauração das obras pela cidade é muito difundido, com o objetivo de se substituir partes de monumentos em rocha que se fragmentam, ou então como restauro de fraturas/fissuras e rejuntes presentes nos monumentos. Em muitos casos, o contraste rocha-argamassa é muito grande, ressaltando demasiadamente a intervenção. Foi observado nos monumentos: Amizade Sírio- 
Libanesa, Dança Branca, Fonte Monumental, Glória Imortal aos Fundadores de São Paulo, Mãe, Monumento às Bandeiras, Monumento a Ramos de Azevedo, Obelisco da Memória e O Ceifador.

Problemas nos recalques das estruturas (desprendimento de blocos), como encontrado na Amizade Sírio-Libanesa, retratam a falta de manutenção que é muito freqüente nos monumentos.

Para a identificação das formas de intemperismo e degradação, tentou-se utilizar inicialmente o atlas de Fitzner \& Heinrichs (2004), tendo-se mostrado pouco prático o seu uso em trabalhos de campo. Desta forma, optou-se por utilizar a terminologia mais simplificada apresentada em Henriques et al. (2005).

O reconhecimento das formas de alteração é útil às etapas preliminares de avaliação do estado de conservação dos monumentos. A terminologia dessas formas é referente ao que pode ser observado a olho nu, sem implicações das causas que as originam.

O depósito superficial analisado em alguns monumentos está intimamente ligado à deposição nas superfícies de substâncias alóctones muito escuras, como: poeira, fuligem da queima de óleo, colonização biológica e partículas advindas dos veículos, formando uma camada pouco aderente. Foi observado nos monumentos: A Menina e o Bezerro, Anhangüera, Nostalgia (Fig. 2), O Ceifador. 


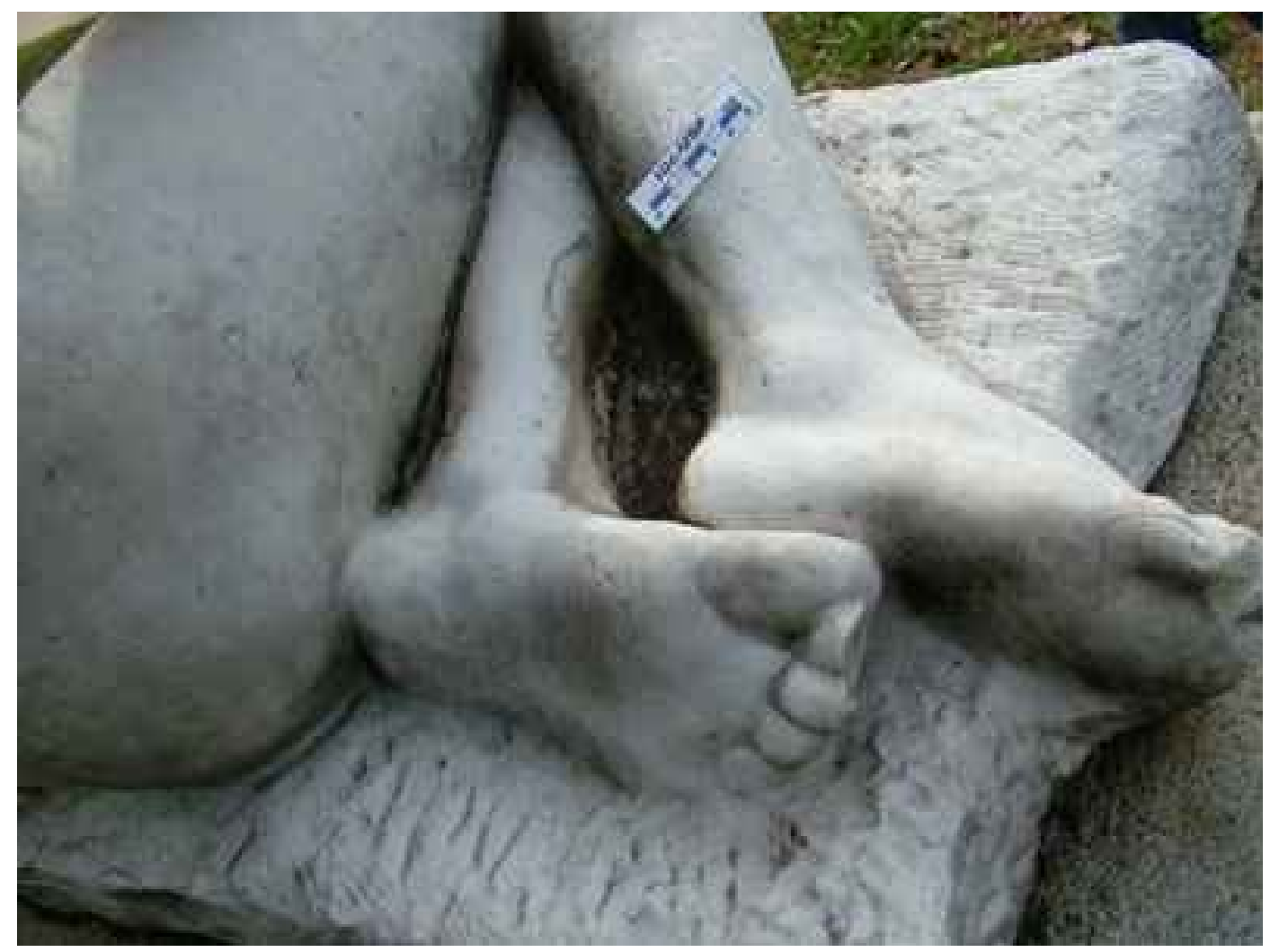

Figura 2

A incrustação também é uma deposição, mas neste caso forma um depósito mais aderente ao substrato. Esta forma de alteração pode ser visualizada, por exemplo, quando o cobre lixiviado do bronze é transportado e depositado nas argamassas do rejunte em monumento de rochas graníticas. O cobre reage com o carbonato da argamassa precipitando carbonato de cobre, que tem coloração esverdeada. Esta precipitação pode se dar no próprio rejunte ou na superfície do granito. Foi observada nos monumentos: Amizade Sírio-Libanesa (Fig. 3), Camões, Cervantes, Duque de Caxias, Fonte Monumental, Os Fundadores de São Paulo, Monumento a Ramos de Azevedo e Padre José de Anchieta. 


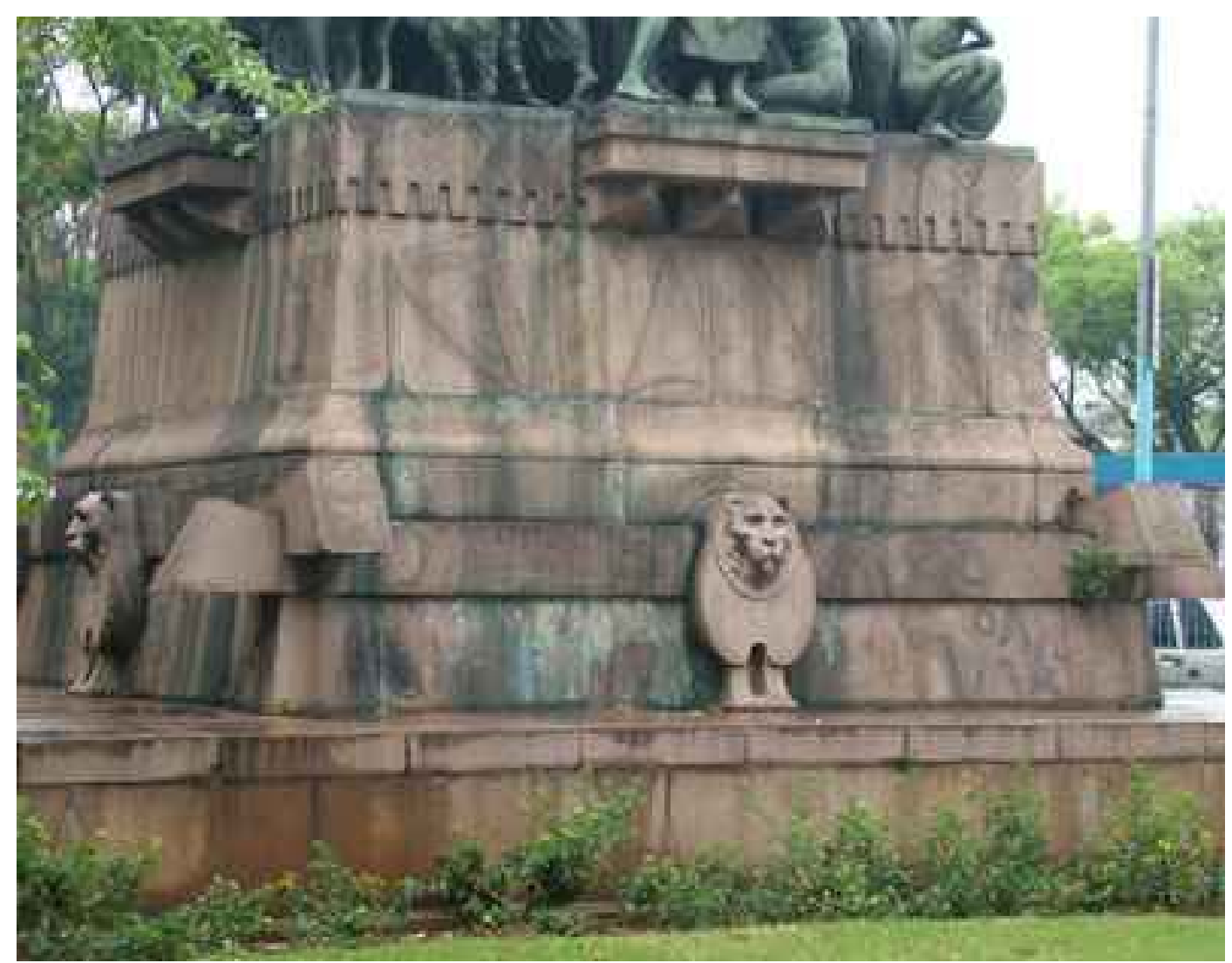

Figura 3

Ocorrem alguns casos em que as superfícies das rochas apresentam-se com alteração cromática, como por exemplo, no Monumento a Carlos Gomes. Neste caso, a alteração parece ser decorrente de uso de produtos químicos utilizados em limpezas na obra. Foi observada também nos monumentos: Amizade SírioLibanesa, Camões, Depois do Banho, Duque de Caxias e Mãe Preta.

Alterações cromáticas mais localizadas são definidas como manchas. Esta feição é observada nos monumentos: Os Fundadores de São Paulo, Glória Imortal aos Fundadores de São Paulo, Monumento a Ramos de Azevedo e Obelisco.

Alveolização é a feição caracterizada por múltiplas depressões centimétricas na superfície rochosa do monumento. Esta feição foi diagnosticada principalmente em rochas carbonáticas, como por exemplo: Anhangüera, Fonte Monumental (Fig. 4), Monumento a Carlos Gomes e Nostalgia. 


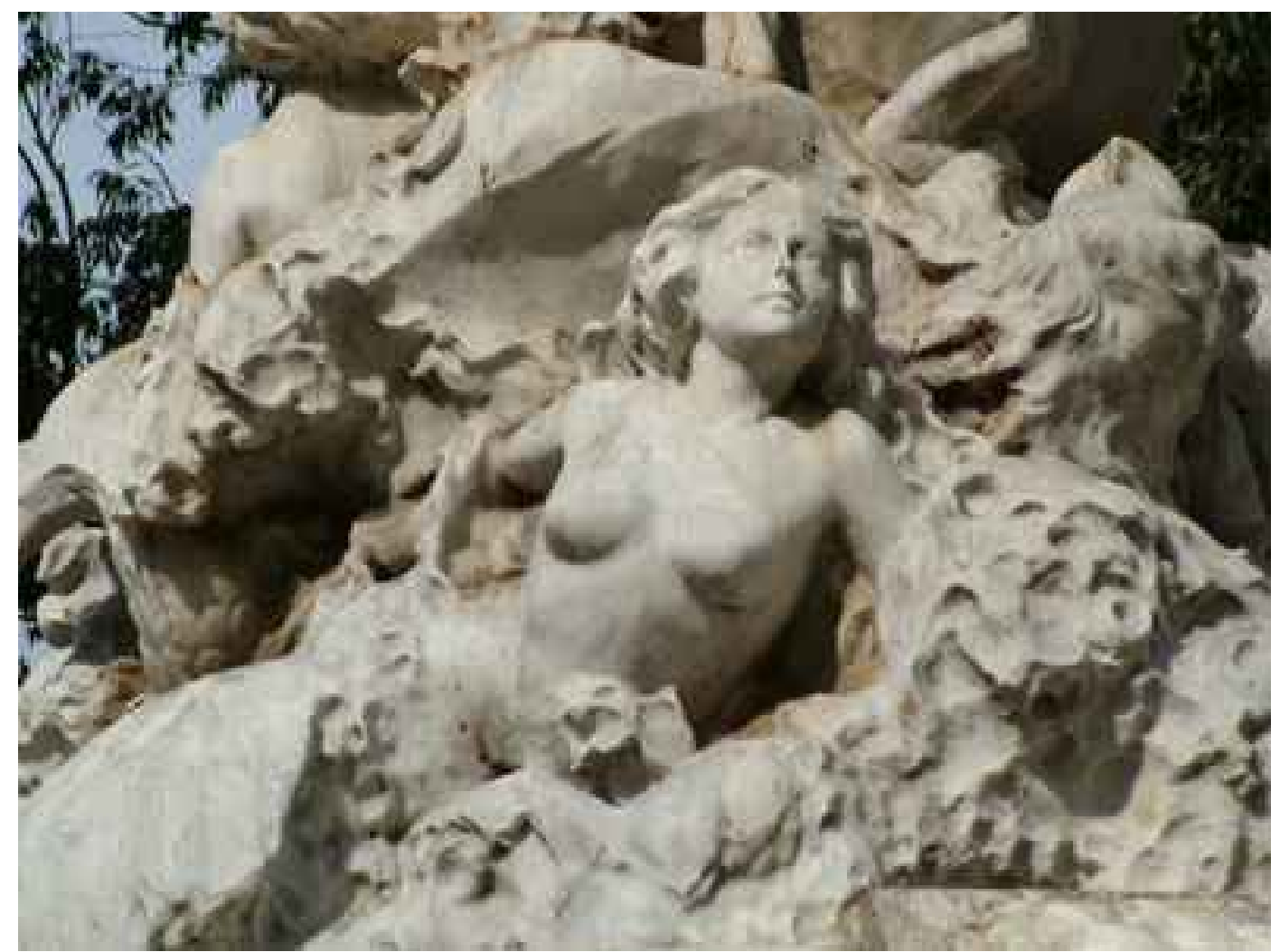

Figura 4

Colonização biológica foi observada em diversas obras, sejam como liquens ou como algas. São facilmente diagnosticadas pela presença de um estrato fino de coloração diversa (branco, verde, amarelo e preto) sobre o substrato. Foi observada nos monumentos: A Menina e o Bezerro, Discóbolo, Os Fundadores de São Paulo (Fig. 5) e Monumento a Carlos Gomes. 


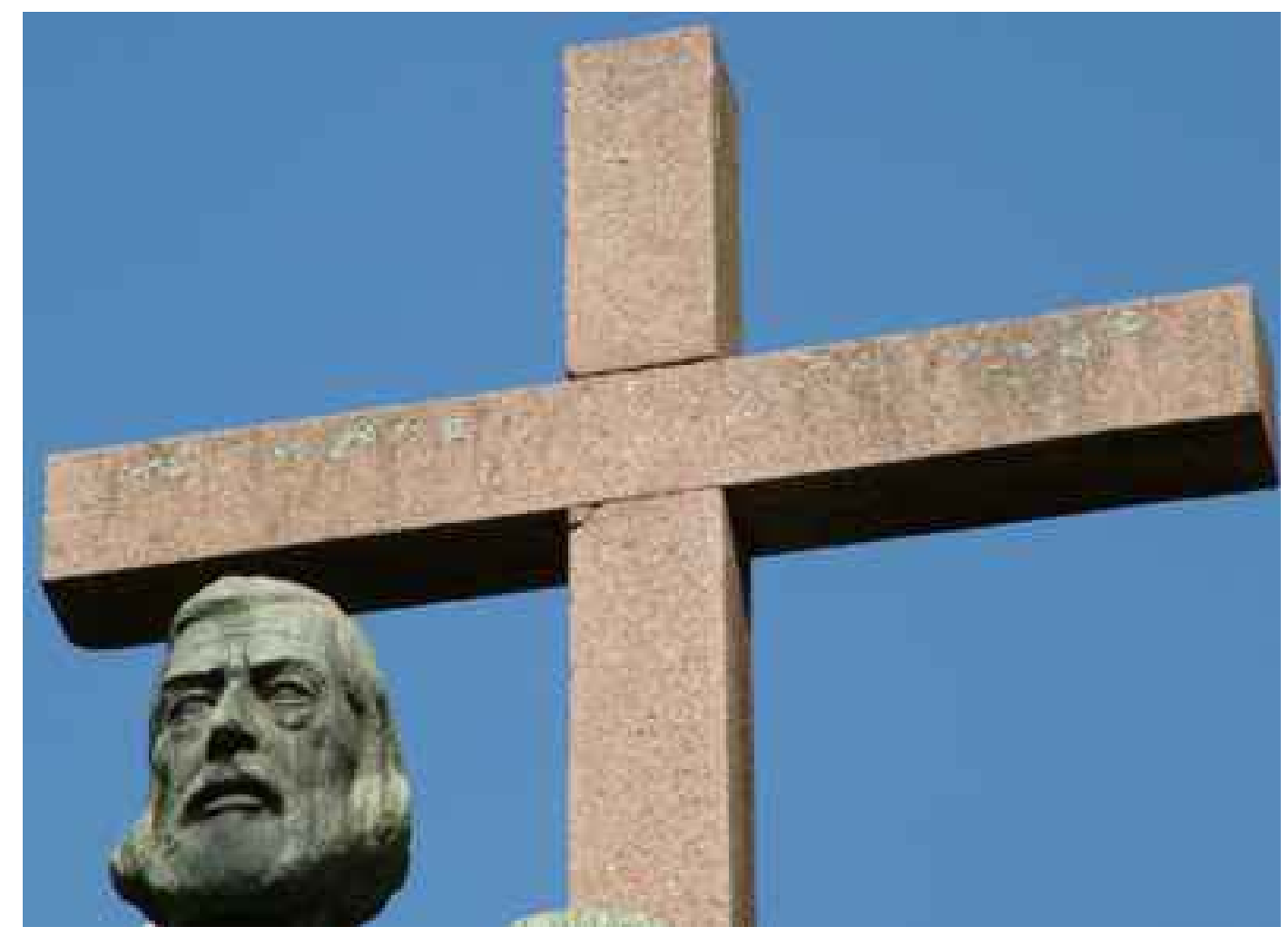

Figura 5

Vegetação - presença de manifestações biológicas, como musgos e plantas superiores. Foi observada nos monumentos: Amizade Sírio-Libanesa, Duque de Caxias, Monumento às Bandeiras e Monumento a Ramos de Azevedo.

Eflorescência é a cristalização de sais superficiais com coloração, geralmente, esbranquiçada, tendo sido observada em Depois do Banho (Fig. 6) e Monumento às Bandeiras. 


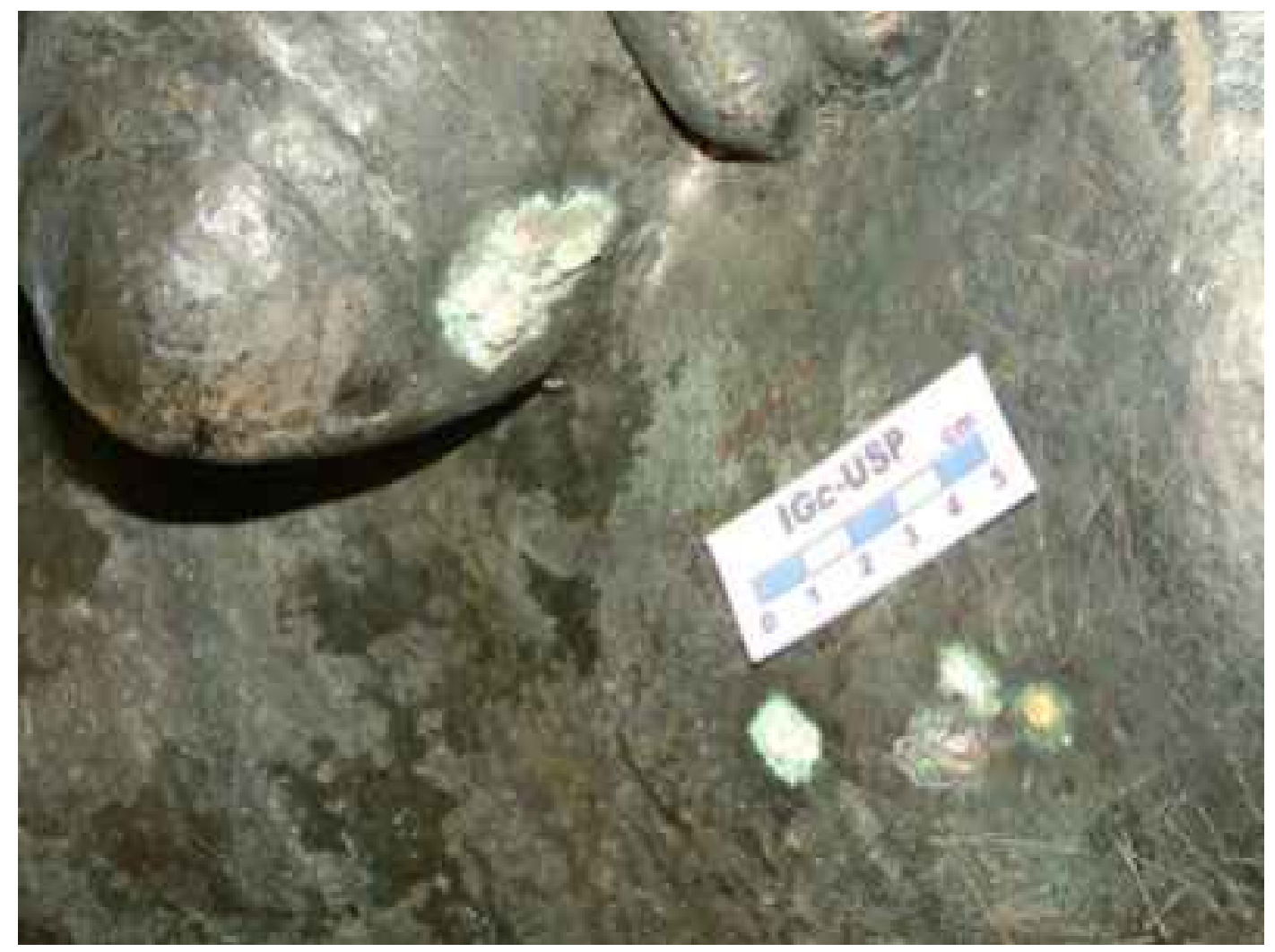

Figura 6

Escamação, lascagem e plaqueta é o destaque de fragmentos rochosos achatados que diferem na espessura e na extensão lateral.

Escamação, consiste em destaque de porções totais ou parciais da rocha em escamas com espessura inferior a $0,5 \mathrm{~cm}$, identificada em algumas bases graníticas. Foi observada nos monumentos: Amizade Sírio-Libanesa, Monumento às Bandeiras e Obelisco da Memória.

Lascagem é a perda de material rochoso, com espessura centimétrica, subparalelo à superfície. Foi observada nos monumentos: A Menina e o Bezerro, Amor Materno, Aretuza, Depois do Banho, Fonte Monumental, Monumento a Carlos Gomes, Monumento a Ramos de Azevedo e Nostalgia.

Plaqueta é a forma de destaque de material rochoso achatado, paralelo à superfície, com grande extensão lateral e com espessura menor que $0,5 \mathrm{~cm}$. Foi observada nos monumentos: A Menina e o Bezerro, Glória Imortal aos Fundadores de São Paulo e Obelisco da Memória (Fig. 7). 


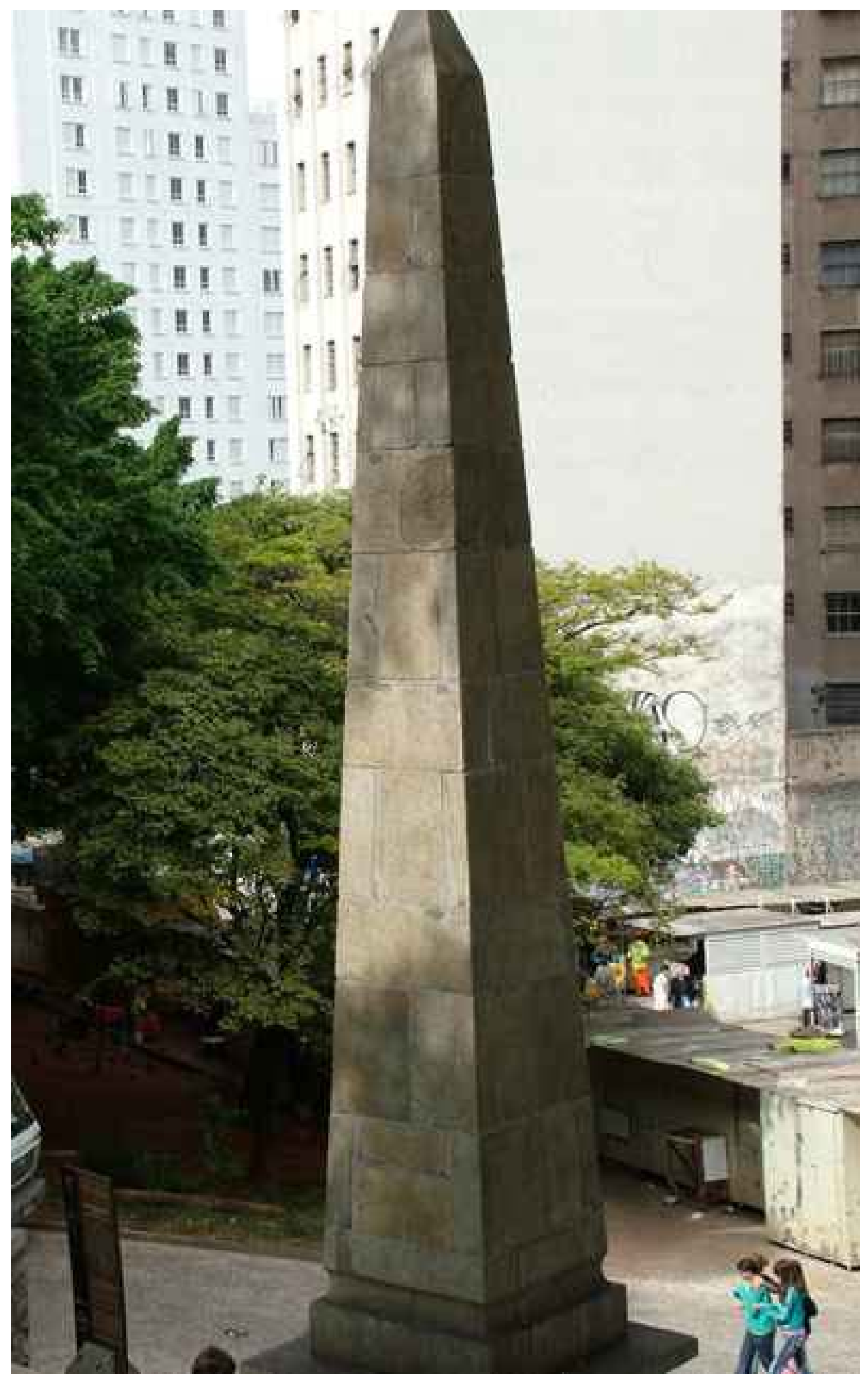

Figura 7 
Muitas obras apresentam fraturas e/ou fissuras em suas bases graníticas. A fissura é identificada como uma descontinuidade na qual ao menos uma das extremidades não atinja o contorno da obra (Fig. 8). A fratura, diferentemente, implica na divisão da obra e pode ocasionar afastamento das partes afetadas do material. Foram observadas nos monumentos: Amizade Sírio-Libanesa, Monumento a Ramos de Azevedo, Anhangüera, Discóbolo, Duque de Caxias, Os Fundadores de São Paulo, Glória Imortal aos Fundadores de São Paulo, Mãe, Monumento às Bandeiras, Monumento a Ramos de Azevedo e Obelisco da Memória.

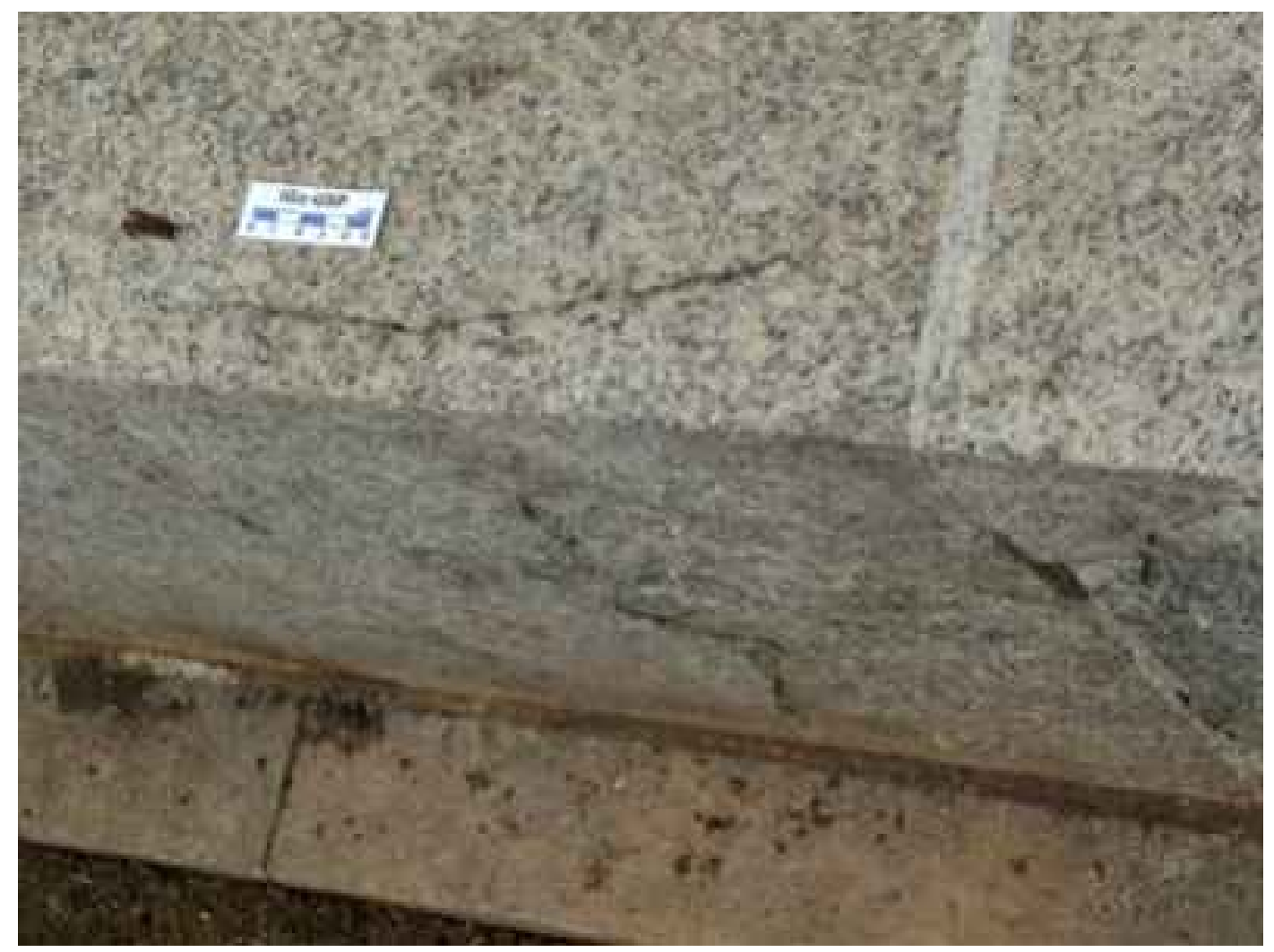

Figura 8

Concreção - A argamassa presente no rejunte pode ser lixiviada e reprecipitada, podendo assumir formas estalactíticas, como observado, por exemplo, nestes três documentos: Duque de Caxias (Fig. 9), Monumento às Bandeiras e Monumento a Ramos de Azevedo. 


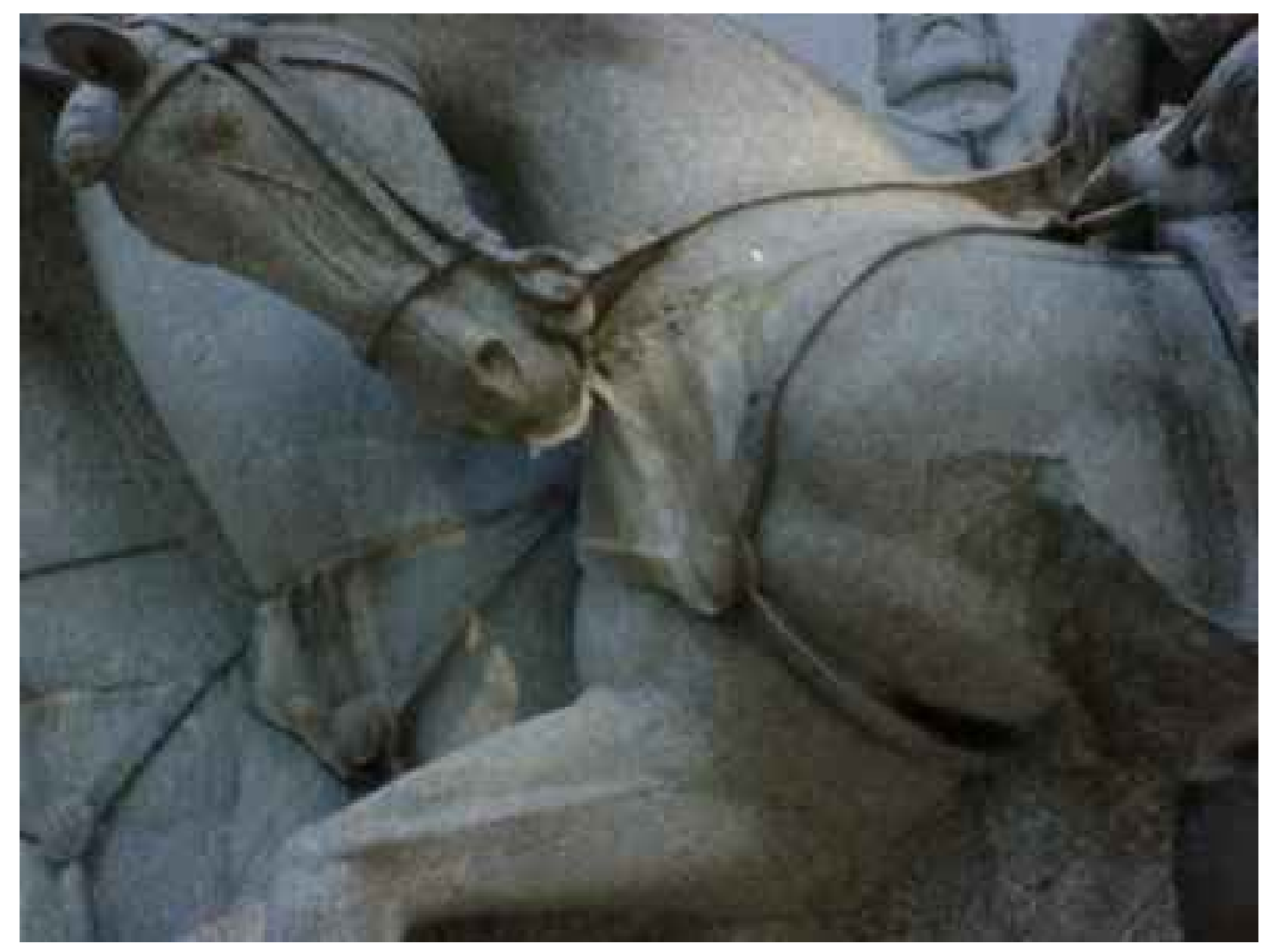

Figura 9

É muito comum a ocorrência de mais de um tipo de alteração no monumento, como foi observado nos diversos monumentos visitados, sendo que a visualização isolada de cada forma presente pode ser dificultada.

Não se pode deixar de mencionar alguns casos em que as obras apresentam-se em ótimas condições de conservação: Fauno (Fig. 10) e Dança Branca, com seus entornos bem cuidados e limpos, e situam-se em parques protegidos com grade. 


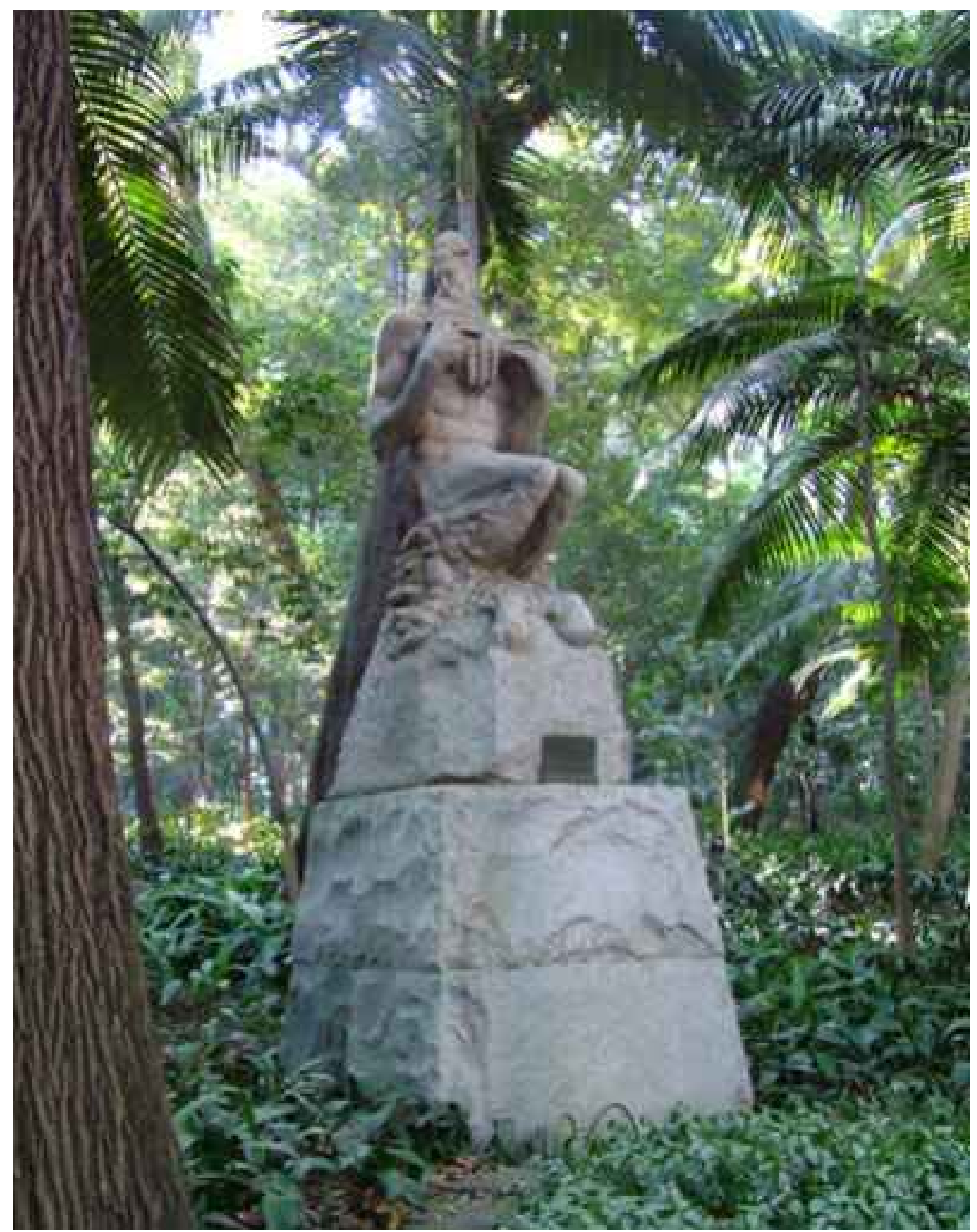

Figura 10

\section{Conclusões}

O levantamento de campo mostrou que o estado dos monumentos estudados é pouco satisfatório. Apesar das alterações intempéricas existentes, a alteração antrópica, representada principalmente por pichações e vandalismo, é o principal fator de degradação dos monumentos. 
A presença excessiva de poluentes atmosféricos (particulados e gasosos) nas áreas urbanas, resultantes de contribuições antropogênicas, pode acidificar as condições ambientais e, conseqüentemente, acentua a decomposição química das rochas. Os principais poluentes são: dióxido de enxofre, cloretos e óxido nítrico. A decomposição de material carbonático por ácidos inorgânicos pode criar sais de sulfato e nitrato que, posteriormente, cristalizam na superfície e fendas das rochas.

Não é possível tratar adequadamente qualquer problema de conservação ou restauro sem o conhecimento das características da rocha, do seu estado de alteração e das causas e mecanismos de deterioração. Para tal, deve-se começar por se estudar as causas de sua alteração: os fatores intrínsecos e os extrínsecos.

A participação da comunidade nas tarefas de preservação patrimonial é imprescindível, visto que a perda da memória cultural será irreparável se ocorrer a destruição dos testemunhos físicos, e deve estar integrada às políticas de conservação do patrimônio histórico.

Para que uma sociedade tenha consciência de seu papel diante da valorização do patrimônio histórico é preciso que haja não só atuação dos poderes públicos, mas também o empenho dos educadores em incentivar a infância e a juventude em cultuar a sua história, educando-os para se abster de qualquer ação que possa degradar os monumentos.

É essencial que a população local tenha consciência da importância e riqueza de seu patrimônio, como por exemplo, o que ocorreu em Santana do Parnaíba, com a recuperação do seu Centro Histórico.

Ultimamente, entidades privadas estão patrocinando o restauro e a limpeza das obras pela cidade. O programa "Adote uma obra artística", por exemplo, é organizado pelo DPH, objetivando a conservação física de obras e monumentos da cidade de São Paulo a partir do apoio da iniciativa privada, tendo já recebido adesões de várias empresas. 
Em relação à conservação dos monumentos, a manutenção e a limpeza devem sempre ser efetuadas com o objetivo de se preservar a superfície do objeto e valorizar o bem patrimonial, eliminando as substâncias nocivas da superfície. Devese atentar aos procedimentos a serem efetuados para não provocar danos estruturais e/ou estéticos nas obras. Por esta razão, é necessário conhecer a rocha em estudo, para se efetuar um diagnóstico correto, e por conseqüência, uma intervenção sem efeitos colaterais, e principalmente que essa intervenção seja mínima, visando preservar o valor histórico da obra.

Diante da carência de mão-de-obra qualificada e recursos financeiros no município precisa-se garantir a formação dos profissionais de conservação e salientar o papel dos conservadores-restauradores, por meio de escolas profissionais e técnicas que garantam um bom aprendizado, não só técnico, como cultural e histórico das obras, criando um sentimento de cidadania na população.

Há uma certa dificuldade em se estabelecer previsões e padronizações quanto ao ritmo da degradação. As dificuldades surgidas refletem o elevado grau de complexidade do processo de intemperismo e das variáveis que o integram.

\section{Notas}

(1) O termo "vândalo" foi citado pelo padre Henri Grégoire em 1794, quando são tomadas as primeiras medidas para deter o vandalismo na França (CAMARGO, 2002).

\section{Referências Bibliográficas}

AIRES-BARROS, Luís. Alteração e alterabilidade de rochas. Lisboa: Universidade Técnica de Lisboa, Instituto Nacional de Investigação Científica, 1991.

CAMARGO, Haroldo Leitão. Patrimônio Histórico e Cultural. São Paulo: Aleph, 2002.

CARTA DE VENEZA. Carta Internacional sobre a Conservação e o Restauro de Monumentos e Sítios. 1964.

CARTA DO RESTAURO. Ministério da Instrução Pública da Itália. Circular nº 17 de 6 de abril de 1972. 
DELGADO RODRIGUES, José. Stone Patina: A controversial concept of relevant importance in conservation. In: DELGADO RODRIGUES, José; MIMOSO, J. Manoel (Eds.). International Seminar - Theory and Pratice in Conservation: a tribute to Cesare Brandi. Lisboa: LNEC, 2006. p. 127-138.

DELGADO RODRIGUES, José. Notas de aula GMG5867 - Conservação e restauração do patrimônio histórico construído, 2006. Disponível em: <http://www.igc.usp.br/disciplinasweb/gmg5867>. Acesso em: 27 out. 2006.

DEPARTAMENTO DO PATRIMÔNIO HISTÓRICO (DPH). Várias pastas sobre obras e monumentos públicos em logradouros municipais.

FITZNER, Bernd; HEINRICHS, Kurt. Photo Atlas of weathering forms on stone monuments, 2004. Disponível em: <http://www.stone.rwth-aachen.de>. Acesso em: 25 jun. 2007.

FITZNER, B.; HEINRICHS, K.; KOWNAZKI, R. Weathering forms: classification and mapping. Berlin: Verlag Ernst \& John, 1995.

FRASCÁ, Maria Heloísa Barros de Oliveira. Qualificação de rochas ornamentais e para revestimento de edificações: caracterização tecnológica e ensaios de alterabilidade. In: SIMPÓSIO BRASILEIRO DE ROCHAS ORNAMENTAIS, 1.; SIMPÓSIO BRASILEIRO DE ROCHAS ORNAMENTAIS DO NORDESTE, 2., 2001, Salvador. Anais... Rio de Janeiro: MCT/CETEM, 2002. p. 128-135.

FRASCÁ, Maria Heloísa Barros de Oliveira. Estudos experimentais de alteração acelerada em rochas graníticas para revestimento. 2003. Tese (Doutorado)-Instituto de Geociências, Universidade de São Paulo, São Paulo, 2003.

HENRIQUES, Fernando M. A.; DELGADO RODRIGUES, José; AIRES-BARROS, Luís; PROENÇA, Nuno. Materiais pétreos e similares: terminologia das formas de alteração e degradação. Lisboa: LNEC, 2005.

INSTITUTO PORTUGUÊS DO PATRIMÓNIO ARQUITECTÓNICO (IPPAR). Mosteiro dos Jerónimos: a intervenção de conservação do claustro. Lisboa: IPPAR, 2006.

PRIKRYL, R.; SVOBODOVÁ, J.; HRADIL, D. Weathering of sandstone sculptures on Charles Bridge, Prague: influence of previous restoration. In: SMITH, Bernard J.; TURKINGTON, Alice V. (Eds.). Stone decay: its causes and controls. United Kingdom: Donhead, 2004. p. 89 -108.

REYS, Aranda Calió dos. Estado de conservação dos monumentos da cidade de São Paulo. Monografia de Trabalho de Formatura-Instituto de Geociências, Universidade de São Paulo, São Paulo, 2006.

SMITH, M. R. Stone: building stone, rock fill and armourstone in construction. London: Geological Society Engineering Geology, 1999. (Special Publication, n.16).

VICENTE, M.A.; DELGADO-RODRIGUES, José; ACEVEDO, J. (Eds.). Degradation and conservation of granitic rocks in monuments. Brussels: European Commission, 1996. (Protection and Conservation of the European Cultural Heritage, Research Report, n.5) 
WILCZYNSKA-MICHALIK, W. Chemical composition of precipitation in Kraków: its role in the stone building materials. In: SMITH, Bernard J.; TURKINGTON, Alice V. (Eds.). Stone decay: its causes and controls. United Kingdom: Donhead, 2004. p. 130-147.

* Geóloga (IGc-USP). E-mail: aranda reys@yahoo.com.br ( consultar Profa M Lúcia)

** Geóloga. Doutora pelo IGCE-UNESP. Professora do IGc-USP. E-mail: edellama@usp.br

*** Geólogo. Pesquisador do IPT. E-mail: Ikdehira@ipt.br

Este artigo foi baseado na Monografia de Trabalho de Formatura de Aranda Calió dos Reys sob a orientação da Profa. Dra. Eliane Aparecida Del Lama. 